\title{
The Unconventional Monetary Policy: A Theoretical Approach
}

\author{
Derya Y1lmaz, Emin Ertürk, and Filiz Eryılmaz
}

\begin{abstract}
The financial crisis that erupted on August 2007, hampered the financial markets. Furthermore; with the fall of Lehman Brothers in September 2008, financial crisis evolved into a full-fledged global crisis and depressed the real economy. Central Banks have responded by altering interest rateconventional monetary policy- initially. But this was not enough to calm the financial markets down and revive the real economy. In this regard, major Central Banks- FED, ECB, BOE and BOJhave begun to use liquidity support, asset purchases and forward guidance, namely unconventional monetary policies. They have expanded their balance sheets accordingly in order to relieve financial market stress and to revive the real economy. In this study, we explore the theoretical background of these policies and assess their effectiveness.
\end{abstract}

Index Terms-Unconventional monetary policy, global financial crisis, central banks.

\section{INTRODUCTION}

Global financial crisis has changed the views about monetary policy. According to Mishkin [1], prior to the crisis, as a consequence of advances in theoretical and empirical studies, most economists and policymakers accepted there existed a well-defined "science of monetary policy". Monetary policy is assigned to ensure price stability and the primary tool is the short-term interest rate. Central banks implement monetary policy by altering short-term interest rate and explaining the monetary policy stance to the public in order to influence expectations. Short-term rates are seen as a signal for money markets and this impulse is transmitted to the entire economy through various channels.

However, due to the turbulence started in August 2007, financial instability hampered the money markets. The uncertainty about solvency of financial markets lead to a mounting counterparty risk. Moreover, with the fall of Lehman Brothers in September 2008, the financial crisis has evolved into a global crisis. In this regard, central banks responded by decreasing official rates until they hit the zero-lower bound. Nonetheless, this could not be transmitted to the money market rates and spreads have risen accordingly. Thus, central banks have to use other tools to address financial market stress and revive the real economy. These tools are: providing liquidity to financial institutions, purchasing assets (public or private) and forward guidance, which are known as unconventional monetary policies. Borio and Disyatat [2] express that a difference between

Manuscript received December 16, 2016; revised March 6, 2017.

Derya Y1lmaz are with Uludag University, Economics, Bursa, 16059, Turkey (e-mail: deryahekim@gmail.com, eerturk@uludag.edu.tr, filizgaygusuz@gmail.com). conventional and unconventional policies might be very tenuous. They also admit that, as these policies alter the magnitude or composition of balance sheets, they could be named as "balance sheet policies".

FED, ECB, BOE and BOJ have used these policies in order to calm financial markets and prevent repercussions to the real economy. Monetary policy has begun to focus on financial stability and growth, rather than price stability. Using unconventional monetary policies have expanded the balance sheets. Total assets of FED have surpassed 4 trillion dollars. Total assets reached approximately 5-fold in FED, $\mathrm{BOJ}$ and $\mathrm{BOE}$ since the beginning of the crisis. It is modest in ECB -nearly 3-fold. Despite using these policies aggressively, real GDP growth could not be record positive values until the first quarter of 2010. Central banks are reluctant to quit these policies. These policies have begun to be named as "conventional unconventional monetary policies". However, have these policies been able to calm the financial markets and revive the real economy?

Bearing in mind the question above; the aim of this study, is to investigate the theoretical background of unconventional monetary policies and analyze the effectiveness of these policies by comparing major central banks. Within this context, first we explain the theoretical background of unconventional monetary policies. Second, the policies used in practice after the financial crisis are discussed. Third, we evaluate the policy performance descriptively. Finally, the last section covers the concluding remarks.

\section{UNCONVENTIONAL MONETARY POLICY}

In normal periods, central banks alter monetary policy rate and this would transmitted to the economy via various channels as mentioned above. However, in time of financial crisis, transmission channels are disrupted. Despite lowering the policy rate; Central Banks could not be able to reduce money market rates. Spreads have risen accordingly. Lowering policy rate has also a limit, policy rate can be decreased until it hits the zero-lower bound. So further monetary ease could not be achieved by decreasing policy rate as conventional monetary policy predicts. According to Mishkin [3], this is not an indication of an impotent monetary policy, this is related to the severity of the crisis. In this regard, Central Banks use other tools to address distortions in the transmission mechanisms and stimulate aggregate demand.

There are two different approaches to unconventional monetary policies. The first one is a sequential approach that is mainly used by FED, BOJ and BOE. Unconventional monetary policy is regarded as a substitute to conventional 
monetary policy. When the policy rate is decreased and hits the zero-lower bound, unconventional monetary policies are used to provide further stimulus. In a New-Keynesian framework, creating inflation via expanding balance sheet could decrease real rates. In the second approach -used mainly by ECB-, unconventional monetary policy is parallel and complementary to conventional monetary policy. Policy rate is set to ensure price stability. Yet during crisis, this rate could not be transmitted to the entire economy. Unconventional monetary policies are used parallel to conventional monetary policy- before interest rate hits zero-lower bound- to address these disruptions in the transmission mechanisms [4].

\section{A. Theoretical Background}

We can classify unconventional monetary policies into three broad categories: (i) liquidity provision to financial markets/institutions, (ii) asset purchases, and (iii) using forward guidance policies to effect long-term yields. Liquidity support to financial institution is not a new function for Central Banks. Since their establishments, Central Banks act as a lender of last resort, either providing direct assistance to individual financial institutions or acting as a leader in the rescue operations [5]. Liquidity support by Central Banks may be vital in the acute phase of the crisis in order to support illiquid institutions and calm the markets.

The second type of unconventional monetary policy is asset purchases. Via purchasing assets, Central Banks targeted the level of reserves of the banks. In normal periods, level of reserves are not targeted, they are by-product. The focus of the policy is price of reserves that clears the market. However; during the crisis, the focus turns out to be on a quantity of reserves. That's why this policy is often referred as "Quantitative Easing". Thus, the aim with rising reserves is to increase lending into the broader economy, and as a consequence of buying assets, rising asset prices. This would eventually remove deflationary forces and stimulate demand [6].

Liquidity support and asset purchases effect the broader economy via two channels. The first one is signaling channel [7]. Through the announcement that central bank would loosen monetary policy further, it becomes a signal for financial markets that they are not left alone [8]. In order to use this channel effectively, central bank credibility is of key importance. Only credible central bank can effect the expectations and lower long-term yields. This in turn stimulates aggregate demand.

The second one is portfolio-rebalancing channel. This channel affects total demand through altering balance sheets of central banks and private sector by asset purchases and liquidity injections. Functioning of this channel depends on the imperfect substitution in private sector balance sheet items. For instance, some investors - such as pension and insurance funds- prefer to hold long-term assets in order to match them with their long-term liabilities. When central bank purchases long-term assets, these investors would gain revenue. With these revenues they would purchase long-term assets again as well. On the other hand, by purchasing long-term assets, central bank would reduce the stock of privately hold assets. The aggregate reduction in stock of long-term assets causes a decline in term premium. This would in turn reduce the long-term yields and increase the long-term asset prices. Increase in asset prices would raise household wealth and stimulate aggregate demand [6].

Injecting liquidity to financial institutions would stimulate the aggregate demand through portfolio-rebalancing channel, in the case of imperfect substitution in private sectors liabilities. This imperfect substitution is driven by asymmetric information. In the case of asymmetric information, external funds are costlier than the internal funds. In times of crisis, asymmetric information is exaggerated [9]. This may lead to a rationing in external funds. Concurrently, providing liquidity to financial institutions by Central Bank, especially with a long maturity, would reduce the long-term spreads [7]. This would in turn stimulate the aggregate demand.

The third type of unconventional monetary policy is forward guidance. This policy is based on Central Banks statements about the path of future policy rates. Central banks altered the short-term rates but the monetary policy stance is in relation with long-term rates. Private sector considers long-term rates while barrowing and investing. In the monetary transmission mechanism, long-term rates play a pivotal role. However, long-term rates are the sum of future expectations of short-term rates -plus risk and liquidity premium- as expectations theory predicts. Therefore, Central Banks try to affect expectations about short-term rates by explaining their intentions about future short-term rates [10]. On the other hand, market participants should believe in that commitment and form their expectations accordingly. Woodford [11] and Bernanke and Reinhart [10] stress the credibility of the Central Bank in using forward guidance. Market participants should believe that Central Bank would not renege from its commitment. Otherwise, the time-inconsistency problem would be apparent.

\section{B. Policies Used after the Global Financial Crisis}

Global financial crisis erupted as a subprime mortgage market crisis in August 2007 in US. This would begin to affect money market overseas, especially the more integrated with US financial markets. Furthermore, with the fall of Lehman Brothers on September 2008, the crisis evolved into a global crisis around the World. Central Banks have addressed the problems in financial markets from the beginning. Yet, in the first phase of the crisis -from August 2007 to September 2008-, Central Bank policies basically dealt with financial market distortions that impaired the transmission channels. After September 2008, as the crisis repercussions were evident in real sector, Central Banks began to aim stimulating aggregate demand.

The major central banks, FED, ECB, BOE and BOJ used extensive measures to alleviate financial market tensions and revive the real economy. ECB provides liquidity in order to calm interbank markets as per the bank-financed nature of Europe's financial system. ECB conducts open market operations through variable tender procedure. But in October 2008, the procedure was changed to a Fixed-Rate Full Allotment (FRFA). With this new procedure, ECB tries to satisfy the liquidity needs of banks at a specified interest rate. ECB has also lengthened the maturity of Long-Term Refinancing Operations (LTRO), from three months to six 
months. Additionally, ECB conducted 1 year LTRO on May 2009 and two 3 years LTROs on December 2008 in order to fulfill long term liquidity needs of banks [12]. Via these operations, ECB became "intermediation of last resort" [13] FED, initially increased the credit from discount window in order to provide liquidity to the banks. Later on, more comprehensive programs were designed, in order to support all banks under the name of Term Auction Facility (TAF) and market maker banks under the name of Primary Dealer Credit Facility (PDCF) [14].

BOE also targeted the interbank money market distortions and provided liquidity accordingly. First of all, spreads in standing facilities were decreased from 100 basis points to 25 basis points. Then, on April 2008, Special Liquidity Scheme program was introduced. The aim was to replace illiquid assets with liquid ones in banks' balance sheets [15]. But these measures were not sufficient for the banks to provide credit to the economy. In order to address this; BOE initialized the Funding for Lending Scheme in July 2012. According to this program, banks could barrow with reasonable rates with the condition to lend to non-financial corporations and households [16].

BOJ started "fund-supplying operations" and lend to banks with a maturity of three months at the policy interest rate in December 2009. The total amount of loans was initially programmed as 10 trillion yen but in March 2010, the amount retched up to 20 trillion yen. In August 2010, 10 trillion yen additional loan was added to the program with a maturity of 6 months. In June 2010, BOJ started Growth- Supporting Funding Facility. In the context of this facility, BOJ provided fund to the growth-enhancing sectors. At the end of March 2014, the outstanding balance of loans reached 3.1 trillion yens. In December 2012, it also started Stimulating Bank Lending Facility that would be channeled to banks in order to stimulate bank-lending activities. At the end of March 2014, outstanding balance of these loans reached 8.5 trillion yen. [17]. BOJ also reacted by supplying loans after an earthquake on March 2011. The upper limit on funding to banks that lend to growth industries was raised to 3.5 trillion yens in June 2011 and to 5.5 trillion yens in March 2012 [18].

Asset prices have also shrunk with the financial crisis. Asset prices are important in market-financed economies like the US and the UK. For households, rising asset prices means soaring wealth and consumption. Furthermore, rising asset prices leads to a rise in equity prices, with substitution and portfolio rebalancing effects. Rising equity prices lead to an increase in investment as Tobin's q theorem predicts. These eventually boost aggregate demand. Thus, Central Banks have purchased assets.

ECB has also purchased assets. But it was yet again to relieve interbank money markets. Primarily, ECB started two Cover Bond Purchase Programs (CBPP) in June 2009 and October 2011, respectively. In these programs ECB purchased bonds that cost 40 billion Euro and 60 billion respectively.

After the Sovereign Debt Crisis, the spreads on sovereign bonds increased tremendously especially in highly indebted countries; Greece, Portugal, Ireland, Spain and Italy. Sovereign bonds are important in the transmission channels. First of all, as they are highly liquid, these bonds are utilized as primary collateral in European repo markets. Furthermore, they could provide a benchmark for other assets used in these transactions. So in order to buy private and government bonds from secondary markets; ECB introduced the Securities Market Program (SMP). With this program, the aim was to prevent bond yields to increase further and provide time for government to find durable solution for the debt crisis. In September 2012, this program was replaced by Outright Purchases Program (OMT), the difference from the predecessor was its conditionality to EFSF/ESM programs, in order to force indebted governments to take on responsibility. Due to stagnant growth in Euro Area, ECB announced "expanded asset purchase programme" on January 2015. In the context of this program, ECB purchases bonds issued by government, agencies and European institutions. The amount of purchases is 60 billion Euros monthly and would be at least 1.1 trillion Euros.

US financial system is market-based so FED purchased substantial amounts of assets. In November 2008, to support credits in housing market, FED started the first Large Scale Asset Purchase Program (LSAPP1), known as Quantitative Easing 1 (QE1). In this program, FED bought 175 billion dollar agency debt and 1.25 trillion dollar mortgage back securities (MBS). This was not sufficient for the markets. Consequently in November 2010, FED announced that it would expand its balance sheet with the second Large Scale Asset Purchase Program (LSAPP2), also known as QE2. In the scope of the program, FED bought 600 billion dollar long-term government bonds [7].

In September 2011, FED started Maturity Extension Program. Under this program, FED bought 400 billion dollar long-term securities and sold the same amount of short-term securities. This program did not expand the balance sheet, it only altered its composition [19]. One year later, in September 2012, as a consequence of weak economic outlook, FED announced the third Large Scale Asset Purchase Program (LSAPP3), known as QE3. It started to buy 40 billion agency mortgage backed securities (Agency MBS). In November 2012, FED added 45 billion dollar government bond to the program [20].

BOE also started Asset Purchase Facility (APF) in January 2009 and bought government bonds (gilts), corporate bonds and commercial paper. The ceiling was 50 billion sterling when it was first announced, but it was raised to 200 billion sterling later on. In October 2011, BoE introduced the second Asset Purchase Facility (APF2). 175 billion sterling worth of assets have been bought under this new program.

In October 2010, as a response to weak economic performance, as mentioned above, BoJ introduced "comprehensive monetary easing". Under this scheme, BoJ established an asset purchase program amount of 5 trillion yen, which is composed of government securities (3.5 trillion yen) and private assets (1.5 trillion yen). After an earthquake; this program was raised to 40 trillion yen. Then the asset purchase program expanded several times to 101 trillion yen, which is nearly $21 \%$ of GDP [18]. In April 2013, BoJ launched "quantitative and qualitative monetary easing". This aimed to increase monetary base by 60 trillion to 70 trillion yen annually [20]. In October 2014, BOJ expanded bond purchases to 80 trillion yen. In the context of this program, 
BOJ increased Japanese Government Bond (JGB) purchases and average maturity of the bonds have been extended from 3 to 7 years. It also purchased risky assets such as Exchange Traded Funds (ETFs) and Japan Real Estate Investment Trusts (J-REIT) [21]. As a consequence, monetary base reached 201.8 trillion yen at the end of 2013, meaning a 63.4 trillion yen increase during 2013 [17].

These major Central Banks attempted to influence long-term interest rates and stimulate aggregate demand accordingly by using forward guidance policies in addition to expanding balance sheets. FED used this policy extensively. Initially in December 2008, Federal Open Market Committee admitted that federal fund rates would be low for a period of time. Then in March 2009, FED extended the duration by expressing the statement "extended period of time". In order to give clear messages, this statement was replaced by a date, mid-2013. Then this date delayed until mid-2015. Finally in December 2012, FED announced that it would keep low interest policy until the unemployment is lower than \%6.5 and inflation does not exceed $2 \%$ at most 1 percentage points.

ECB also attempted to affect long-term yields by using forward guidance policies. In July 2013, Governing Council announced that ECB would keep the interest rate lower for an extended period of time. BoE used this policy from August 2013 as a response to the weak growth and employment dynamics. Monetary Policy Committee expressed that unless the inflation expectations exceeded the target $-2 \%$ - by about half a point and financial instability poses a threat, this low policy rates would be continued [16].

BoJ used forward guidance policy by referring its inflation target. In October 2010, BoJ stated that it "will maintain the virtually zero interest rate policy until it judges on the basis of the understanding medium to long-term price stability." In January 2013, BOJ clarified this inflation target by expressing $2 \%$ point estimate and in April 2013, with the announcement of "quantitative and qualitative monetary easing" expressed its intention to meet this target over about 2 years [18], [19].

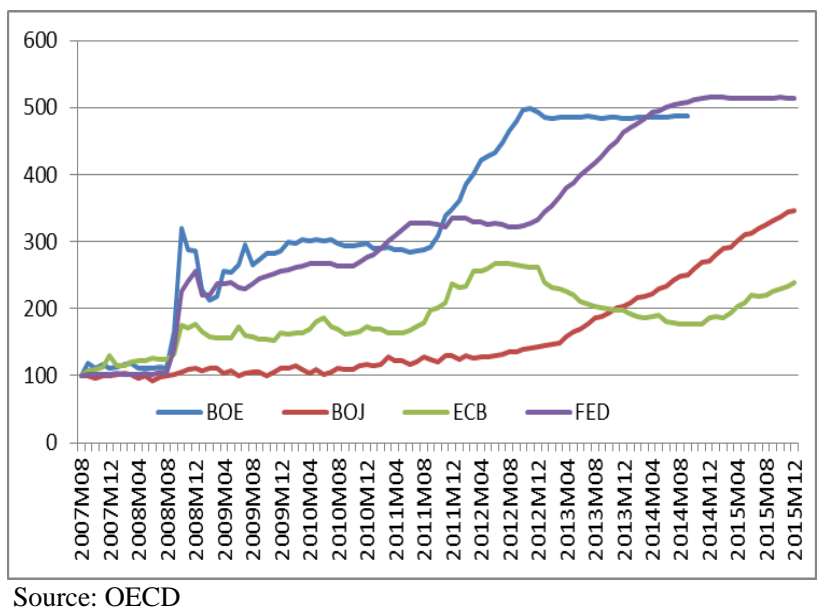

Fig. 1. Total Assets of Central Banks $(2007 / 08=100)^{1}$.

These policies were reflected as an expansion in balance sheets as demonstrated in Fig. 1. Balance sheets of FED and BOE expanded seriously, which exceeded 5 fold in FED and approximately 5 fold in BOE. The expansion in ECB balance

\footnotetext{
${ }^{1}$ The latest data on the total assets of BoE was belonged to October 2014
}

sheet was modest compared to FED and BOE. Despite accelerating after financial crisis; as past LTROs have been falling due, ECB's assets began to decline from the beginning of 2013. But after the expanded asset purchase programme-that began on January 2015- balance sheet of ECB has begun to rise again. With the beginning of quantitative and qualitative easing program, announced in April 2013, BOJ have begun to expand its balance sheet further. The cumulative increase in total assets of BOJ between 2007/08 and 2013/03 -in 68 months- was 63\%, the cumulative increase after quantitative and qualitative easing program in 16 months was also 63\%. This could also be observed in Fig. 1.

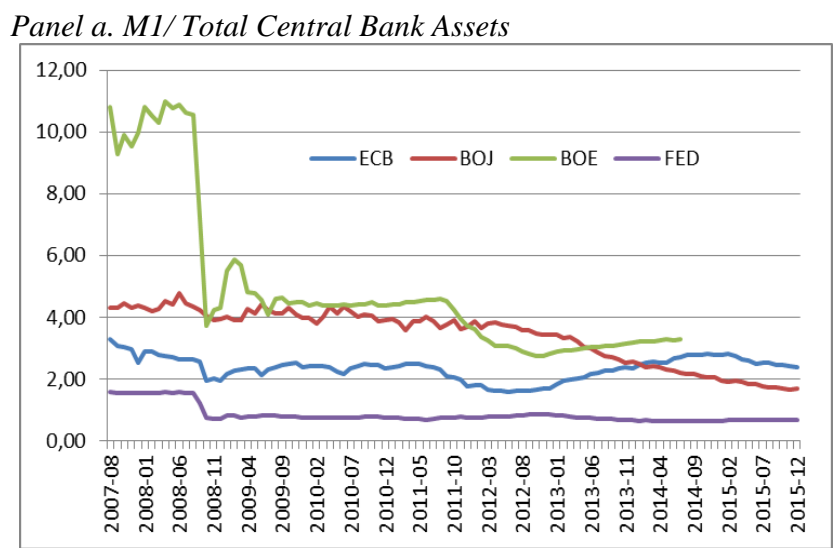

Source: Central Banks' webpages and own calculations.

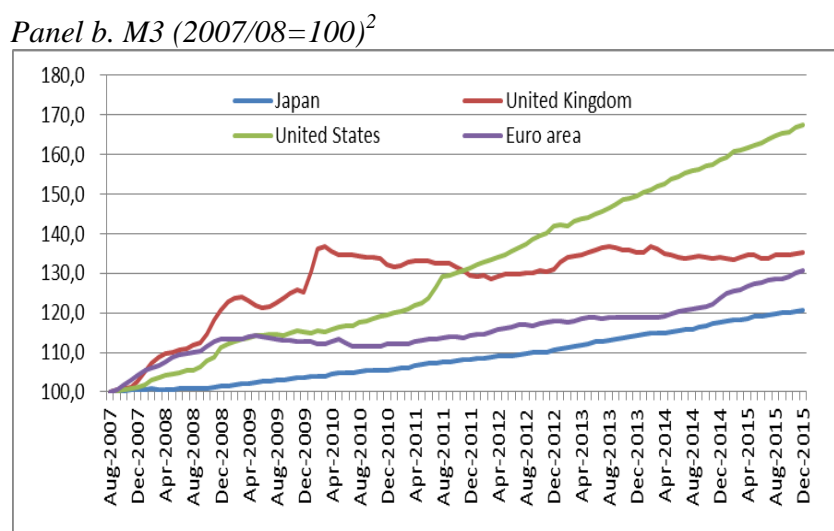

Source: OECD

Fig. 2. Monetary reflections

When this expansion was observed from the monetary point of view, the situation was different. Despite rising balance sheets, monetary aggregates have not been increased as much. In Panel a of Fig. 2, one could observe the M1/ Total Central Bank Assets ratio. This simply reflects how much money created by central bank has diffused into the economy. Especially after Lehman's collapse, in all economies this ratio has begun to decline. The dramatic decline have been experienced in UK. The reason behind this was the tremendous expansion of BOE's total assets. In October 2008, total assets of BOE rose to 93 percent- that could also be observed in Fig. 1- but M1 rose only 0.1 percent. In Panel b of Fig. 2, one could view the development of broad money, M3, as an index. In all countries, M3 has been on a rising trend,

\footnotetext{
${ }^{2}$ Fed stopped announcing M3 data since March 2006. But some private institutions continued to estimate the data. This study have acquired the data as an index from OECD.
} 
but this increase was very small compared to the balance sheet expansion. In the US, the cumulative increase in this period was 67 percent. It was far above the other economies but very small compared to the expansion in balance sheet. The reason behind this fact was the rise in excess reserves of financial institutions. Central Banks have used unconventional monetary policies that aimed to increase reserves of financial institutions, but these institutions were reluctant to channel these as credits to the entire economy. Because, the confidence was eroded in the markets and could not be recovered afterwards. So, the financial institutions held excess reserves for rainy days even Central Banks paid negative interest rates.

\section{Policy Performance}

Central Banks have used various unconventional monetary policy tools in order to relieve financial market stress and revive the real economy. This study will evaluate these policies' performance initially by looking at the data from financial and real sectors of the economies.

First of all, we could gauge the policy performance by evaluation even if these polices were able to decrease the financial stress. In order to gauge financial stress, the study will use implied stock market volatility index (VIX). VIX index has been regarded as "financial fear index". This means; a rise in this index simply reflects a rise in fear and uncertainty in stock markets. Fig. 3 displays the VIX indices for Eurozone (VIXEZ), US (VIXUS), Japan (VIXJP) and UK (VIXUK). After the fall of Lehman Brothers, these indices skyrocketed and Central Banks responded by using unconventional monetary policies. Financial stress has diminished afterwards. However, in the aftermath of the earthquake and general elections stock market volatility faced an increase in Japan. On the other side, when the sovereign debt crisis intensified and the rumors about Greece's exit became apparent, implied stock market volatility rose in Eurozone. But in either case, the indices never reached levels experienced during Lehman's collapse.

We use volatility indices of CBOE, FTSE 100, Euro Stoxx 50 and Nikkei 225 for US, UK, Euro Area and Japan respectively.

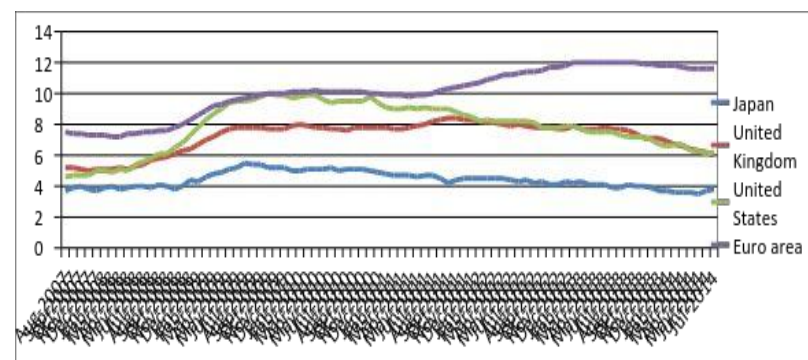

Source: Thomsons' Reuters Datastream and Central Bank Webpages. Fig. 3. Implied Stock Market Volatility Indices (VIX).

In order to evaluate the policy performance on real economy the study will analyze the real GDP growth and unemployment rate respectively. In Fig. 4, real GDP growth rate could be observed. In the first quarter of 2009, all countries recorded very low real GDP growth rates. Real GDP growth was $-9.2 \%$ in Japan, $-5.8 \%$ in UK, $-5.5 \%$ in Eurozone and $-3.5 \%$ in the US in this quarter. With the beginning of 2010, economies began to recover. But the earthquake in Japan and Sovereign Debt Crisis in Eurozone hampered the recovery and these economies experienced negative growth rates accordingly. In Japan; Shinzo Abe took power in late 2012, then the Japanese economy began to recover more swiftly with the new economic program known as "Abenomics". But in the Eurozone, the recovery remained sluggish. Even German economy was stagnant during 2013. On the other side; in the US and the UK, real GDP growth has recorded positive values. Despite being low- especially in the UK between 2012 and 2013- growth has been persistent.

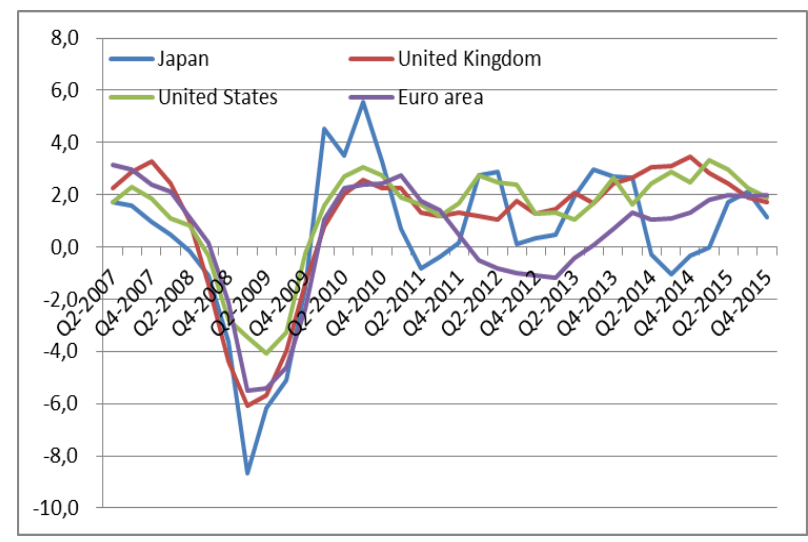

Source: OECD

Fig. 4. Real GDP growth rates.

In Fig. 5, we can evaluate the policy performance on real economy by assessing the progress on labor markets. As could be observed in the figure, unemployment rate was high in Eurozone even in the beginning of the financial crisis. When financial crisis spread to real economy, unemployment rate increased further and approached 10 percentage points on average. The second breakpoint occurred with the sovereign debt crisis and unemployment rate hit 12 percentage points on average. It is important to note that, Eurozone was not able to decrease the unemployment rate. In the US and the UK unemployment rate increased with the crisis- especially in the US this increase was nearly $6 \mathrm{pp}$ - but with the recovery, it approached to pre-crisis values. In Japan unemployment is lower compared to the other counterparts. It increased slightly with the crisis but turned to its pre-crisis level immediately.

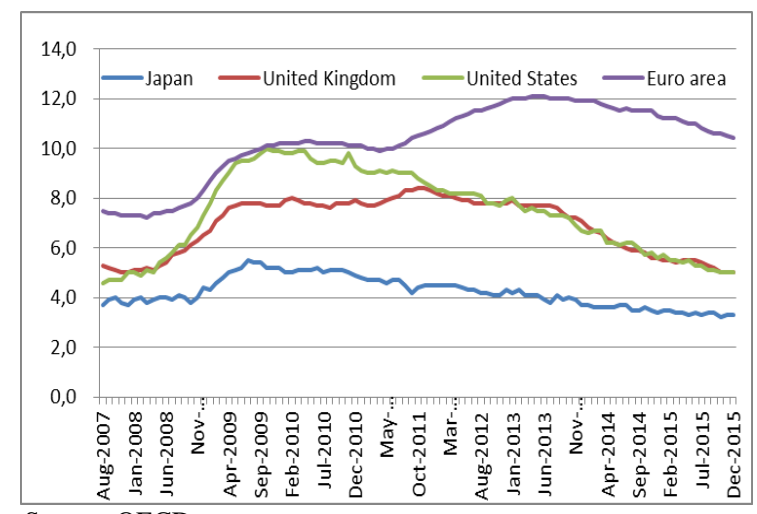

Source: OECD

Fig. 5. Unemployment rates.

\section{REFERENCES}

[1] F. S. Mishkin, "Monetary policy strategy: Lessons from the crisis," NBER Working Papers, no. 16755, 2011. 
[2] C. Borio and P. Disyatat, "Unconventional monetary policies: An appraisal,” BIS Working Papers, no. 292, 2010.

[3] F. S. Mishkin, "Is monetary policy effective during financial crisis?" NBER Working Papers, no. 14678, 2009.

[4] M. Uchida, "Towards the end of deflation in Japan? Monetary Policy under Abenomics and the Role of Central Bank," Reveue de l'OFCEAnalyse et previsions, no. 135, pp. 243-257, 2014.

C. Goodhart, A. E. Schoenmaker, and D. Schoenmaker, "Should the functions of monetary policy and banking supervision be separated," Oxford Economic Papers, vol. 47, no. 4, 1995.

[5] M. Joyce, D. Miles, A. Scott, and D. Vayanos, "Quantitative easing and unconventional monetary policy - An introduction," The Economic Journal, vol. 122, no. 564, pp. 571-588, 2012.

[6] M. Cecioni, G. Ferrero, and A. Secchi, "Unconventional monetary policy in theory and in practice," Occasional Papers, no. 102, 2011.

[7] C. Bowdler and A. Radia, "Unconventional monetary policy: The assessment," Oxford Review of Economic Policy, vol. 28, no. 4, pp. 603-621, 2012.

[8] F. S. Mishkin, "Anatomy of a financial crisis," NBER Working Paper Series, no. 3934, 1991

[9] T. Wu, "The term auction facility's effectiveness in the financial crisis of 2007-09," Economic Letter, Federal Reserve Bank of Dallas, vol. 5, 2010.

[10] S. B. Bernanke and V. R. Reinhart, "Conducting monetary policy at very low short-term interest rates," American Economic Review, vol 94 , no. $2,2004$.

[11] U. Szczerbowicz, "The ECB's unconventional monetary policies: Have they lowered market borrowing costs for banks and governments?" in Proc. European Summer SymposiumIn Internatıonal Macroeconomıcs (ESSIM), TCMB, İzmir, 21-22 May, 2012.

[12] D. Gionnoe, M. Lenza, H. Pill, and L. Reichlin, "Nonstandard monetary policy measures and monetary developments," ECB Working Paper Series, no. 1290, 2011.

[13] M. Labonte, "Financial turmoil: Federal reserve policy responses," Congressional Research Service, July 2010.

[14] OECD, Economic Survey and Country Surveillance: Japan, OECD Publishing, 2013.

[15] BOE, "The funding for lending scheme," Bank of England, Quarterly Bulletin, pp. 306-320, 2012-Q4.
[16] BOJ, "The money market operations in fiscal 2013," Report and Research Papers, August 2014

[17] Gert Peersman, "Macroeconomic effects of unconventional monetary policy in the Euro Area," CEPR Discussion Papers, no. 8348, 2011.

[18] M. Labonte, "Federal reserve: unconventional monetary policy options," Congressional Research Service, November 2013.

[19] IMF, "Unconventional monetary policies - Recent experience and prospects," International Monetary Fund, 2013.

[20] V. Virmani, "Unit root tests: Results from Some recent tests applied to select indian macroeconomic variables," EconPapers, 2004

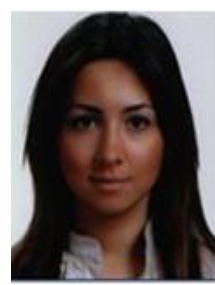

Derya YIImaz is a research assistant doctor who is working as a part of the Faculty of Economics and Administrative Sciences of Uludag University in Bursa/Turkey. She holds a Ph.D. degree from Uludag University. Her current research is focused on the fields of monetary policy, economic and debt crisis.

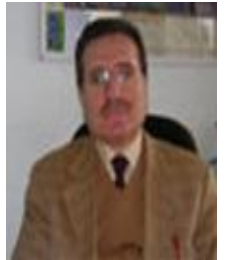

Emin Ertïrk is a professor who is working as part of the Faculty of Economics and Administrative Sciences of Uludag University in Bursa/Turkey. He holds a Ph.D. degree from Uludag University. His current research is focused on the fields of international economics, economic history, economic integration and monetary policy.

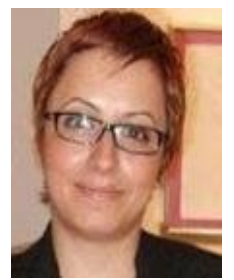

Filiz Eryılmaz is an assistant professor who is working as part of the Faculty of Economics and Administrative Sciences of Uludag University in Bursa/Turkey. She holds a Ph.D. degree from Uludag University. Her current research is focused on the fields of political economics, political business cycles and economic crisis. 